UDK 616.831-001-092:616.714.1-089.873

\author{
Luis Rafael Moscote-Salazar ${ }^{1}$, Hernando Raphael Alvis-Miranda ${ }^{1}$, Gabriel Alcala-Cerra ${ }^{1}$, \\ Andres M. Rubian 2, 3 \\ ${ }^{1}$ Department of Neurosurgery, University of Cartagena, Cartagena, Colombia \\ 2 Faculty of Medicine, South Colombian University, Neiva, Colombia \\ ${ }^{3}$ Director, The Foundation for Medical Education and Research «Meditech», Neiva, Colombia
}

\title{
Decompressive craniectomy in traumatic brain injury: Quo Vadis?
}

\begin{abstract}
Intracranial hypertension is the leading cause of mortality in patients with cranial injury. Currently the traumatic brain injury is a public health problem worldwide. Decompressive craniectomy emerges as a treatment strategy for patients with refractory intracranial hypertension. The completed surgery requires careful surgical technique and exquisite. We present a review of the literature about the technique.
\end{abstract}

Key words: neurotrauma, traumatic brain injury, decompressive craniectomy.

Ukr Neyrokhir Zh. 2014; 4: 4-10.

Received, August 14, 2014. Accepted, September 19, 2014.

Address for correspondence: Dr. Luis Rafael Moscote-Salazar, University of Cartagena, Cartagena, Colombia, e-mail: mineurocirujano@gmail.com

\section{HISTORY OF DECOMPRESSIVE CRANIECTOMY}

The decompressive craniectomy (DC) as a procedure was first described by Annandale in 1894 [1, 2]. In the last part of the XIX century, almost all neurosurgery pioneers had been performed craniectomies as a palliative measure for patients with intractable tumors, but Kocher in 1901, was the first one to propose the palliative decompressive craniotomy for patients with raised intracranial pressure following traumatic brain injury (TBI) [3]. The collaboration of Kocher with Harvey Cushing resulted in the proposition of the use of DC for the treatment of other brain disorders such as vascular malformations and brain tumors, through subtemporal and suboccipital decompressions [4, 5]. Cushing in 1908 [6] published the subtemporal decompressive operations for the intracranial complications associated with bursting fractures of the skull.

The procedure described by Annandale gained popularity in the early 1970 's, but due to poor clinical outcomes, quickly fall into discredit [1,2], and was almost abandoned when experimental evidence [7] suggested that decompression worsen cerebral oedema. In 1968, Clark et al, reported 2 cases with $100 \%$ of lethality [8]. In 1971, Kjellberg et al [9], reported 73 cases, using large bifrontal craniectomy with $18 \%$ of surveillance. Venes and Collins, in 1975, reported in a retrospective analysis of 13 patients who had bifrontal decompressive craniectomy for the management of posttraumatic cerebral edema, a significant decrease in expected mortality, but severe morbidity in the survivors, and only one patient returned to the pretrauma level of neurological function [10].

However, throughout the 1980's its popularity returned. Pereira et al in 1977 , present the results observed with large bifrontal decompressive craniotomy performed on 12 patients with severe cerebral oedema, a $50 \%$ surveillance and $41.6 \%$ of excellent neurological and mental improvement [11]. In 1980, Gerl and
Tavan report that extensive bilateral craniectomy with opening of the dura offers the possibility of rapid reduction of intracranial pressure. In this study, with 30 patients shows a $70 \%$ of mortality, and a $20 \%$ of the cases with full recovery [12]. In 1990, Gaab et al [13], with a prospective study design with 37 patients $<40$ years old, they performed 19 bifrontal craniotomies and 18 hemicraniotomies, and report 5 deaths, all others achieved full social rehabilitation or remained moderately disabled; they established as best predictor of a favorable outcome an initial posttraumatic Glasgow coma scale (GCS) $\geq 7$.

In addition to these promising clinical results, new data suggested that complications of TBI may be reduced following early decompression [14-17].

\section{TRAUMATIC BRAIN INJURY (TBI):}

\section{A CRITICAL PUBLIC HEALTH PROBLEM}

Morbidity and mortality, due to injuries, is being recognized as a major public health and a development problem. It ranks among the leading causes of death and occurs in all regions, affecting people in all age and income groups [18]. TBI is a major public health concern worldwide, according to the predictions, neurotrauma will account an increasing number of deaths worldwide by 2020 [19].

The Centers for Disease Control and Prevention (CDC) has defined TBI as an injury to the head arising from blunt or penetrating trauma or from acceleration/ deceleration forces associated with one or more of the following: decreased level of consciousness, amnesia, objective neurological or neuropsychological abnormality(ies), skull fracture(s), diagnosed intracranial lesion(s), or head injury listed as a cause of death in the death certificate $[20,21]$.

The CDC has estimated that every year, during 2002-2006, on average 1.7 million persons had a TBI alone or a TBI associated with other injuries and/or 
medical conditions [21]. TBI is associated with mortality rates as high as $30 \%$ and also with high morbidity [22, 23]. There is a significant percentage of TBI related deaths that occur relatively late, these are secondary to multiple organ failure and infectious complications, such as pneumonia [22, 24, 25].

TBI is the most common cause of death and disability in children and young adults [26]. In the United States, this kind of injury generate 235.000 hospitalizations, 50000 deaths, and permanent disability in 99000 [26]. The economic burden for TBI alone in the United States in 2000 was estimated in $\$ 110$ billion derived from direct (e.g. medical) and indirect (e.g. lost productivity) costs [27].

One of the main characteristic of TBI is that patients without a severe TBI, can experience subsequent mental and/or medical problems [28, 29]. The acute consequences of TBI are just only a half of the complete problem, the long-term repercussions of TBI are substantial especially among adolescents and young adults, whose brains continue to mature and develop [30]. Approximately 293,000 persons with ages between 15 to 24 years old, sought emergency department treatment for TBI in the United States in 2010 [31].

People who sustain TBI during or before adolescence can have a limited return to pre-trauma academic or work activities that aggravates the economic and physical consequences derived from the treatment and the rehabilitation. Furthermore, they may have diminished attainment of personal milestone [32-34].

When all the costs of severe TBI are considered, aggressive treatment is a cost-effective option, even for older patients [35].

\section{INTRACRANIAL HYPERTENSION (ICH)}

Morbidity and mortality related to brain injury mostly results of brain edema, In neurotrauma, brain edema leads to an elevation in intracranial pressure (ICP), altering physiologic parameters like the cerebral perfusion pressure (CPP) and then brain oxygenation [36]. Edema formation plays a role to the resulting pathology following TBI [37], is a secondary injury caused by a cascade of mechanisms initiated at the moment of injury. In the pathophysiology of the primary and secondary lesions in TBI are the targets to prevent and wane the progression of brain damage.

Intracranial hypertension is a frequent complication of severe TBI [38-40]. Close than $70 \%$ of brain injured patients will present ICH [41-44]. TBI is the most common cause of intracranial hypertension [45]. ICH is the most frequent cause of death and disability following severe TBI [46-48]. ICH (defined as ICP ?20 $\mathrm{mmHg}$ ) is a known independent risk factor for poor neurological outcomes [49].

ICP is determined by the volume of its contents: brain, blood and cerebrospinal fluid (CSF). As stated by Monroe-Kelly doctrine [50, 51], «the sum of the intracranial volumes of blood, brain, CSF and other components is constant and that an in increase in any one of these must be offset by an equal decrease in another» [52], so the skull is a rigid structure, inextensible, in order to maintain a constant blood pressure, the volumes inside the cranium should be constant. Any increase or an additional volume (e.g., haematomas, oedema, hyperemia), will carry an increase in the ICP, and must result in a decrease in the others. Alterations in brain autoregulation, blood flow, and brain edema, persists are consequences of raised ICP.

TBI patients with refractory ICH, have worst outcomes, and more likely to development herniation syndromes [53, 54]. A CPP lesser than $60-70 \mathrm{mmHg}$ is associated with diminished oxygenation and altered metabolism in brain parenchyma [55].

The raised ICP results in «spatial compensation», i.e., extrusion of CSF and blood (mainly venous) from the intracranial cavity. CSF has a key role in spatial compensation because it can be expelled to the spinal theca, the reservoir $[56,57]$. In the intracranium can be stored $150 \mathrm{~mL}$ of new volume without a significant increasing of the ICP, this occurs because the venous blood can be derived to the general circulation [50]. Should be remembered that CSF shift is time- and agedependent variable. Older people can accommodate more of the expanding new volume due to the additional space created by cerebral atrophy, conversely, young people get symptomatically faster, due to the lack of space.

Among deleterious effects of increased ICP is the shift of brain parenchyma resulting in structural damage to the brain and to herniation syndromes. The latter can result in compression on the brainstem causing bradycardia and hypertension and, if untreated, respiratory depression and death [58-60].

In the context of raised ICP, the cerebral perfusion pressure (i.e., difference between ICP and mean arterial blood pressure) generally decrease, contributing to sacrifice cerebral blood flow and generating ischemia and neuronal death, but reduced CPP is associated with the hypoxic/ischemic injury regardless of the $\operatorname{ICP}[45,61]$.

\section{THE NEUROSURGICAL TECHNIQUE [62]}

There are two kinds of craniectomies: hemicraniectomies and bilateral craniectomies.

When making the surgical plan there are some factors to be considered: location, hemisphere, size of the decompression, dural technique, the bone flap, etc. The CT scan will offer large determination of the location (frontal, temporal, parietal, occipital), and hemisphere (uni/bilateral). Some indications for decompressive hemicraniectomy are the unilateral lesions, such as unilateral swelling, contusions, extradural or subdural hemorrhage, midline shift [63], generally is required bifrontal decompression for diffuse cerebral edema with no obvious midline shift [63].

When the decision has been taken, should try at maximum to do bone removal as large as possible, has been recommended that the size of the decompression be, at a minimum, $14 \mathrm{~cm}$ (anteroposterior) by 12 $\mathrm{cm}$ (superoinferior) if the intention is to perform a frontotemporoparietal craniectomy [64].

The ideal technique implies the removal of bone in the entire supratentorial hemicranium. One of the most important landmarks for this procedure is the root of the zygoma, it allows the identification the floor of the temporal fossa. Also are important landmarks: the asterion (confluence of the lamboid, occipitomastoid, and temporoparietal sutures, indicates the area of transition between the transverse and sigmoid sinuses), the 
keyhole (identifies the pterion and indicates the location of the frontal, temporal, and orbital cavities), the inion, the glabella, and the midline (delineates the course of the superior sagittal sinus). When the patient's head is placed in the headholder, it is ideal that the sagittal plane of the head be $0-15^{\circ}$ horizontal to the floor [65].

skin incisions for decompressive hemicraniectomy

Because the objective is the exposure of the entire hemicranium, there are two incisions that allow this goal to be achieved.

1. Large reverse question mark frontotemporoparietal incision

This incision is quick and easy, but has the potential risk of flap ischemia and dehiscence of the wound. It begins at the widow's peak, continues posteriorly along the midline to the inion, it then turns sharply to the ear parallel to a line extending from the inion to the root of the zygoma [66]. The incision should skirt the superior and anterior portions of the ear as closely as possible and extend $1 \mathrm{~cm}$ below the root of the zygoma. With this incision the hemicranium is exposed at the midline, along the line of the transverse sinus. Also permits a great temporal fossa exposition. Skirting the ear avoids the superficial temporal artery; it ensures a good blood flow to the skin flap [67]. Now, the periostium can be incised using an electrocautery knife, and then, the cutaneous flap can be reflected. The temporalis muscle can be reflected in two ways [67]:

- Reflect the skin anteriorly as a separate layer of muscle, this facilitate the temporalis muscle reflection.

- Reflect the muscular and the cutaneous flaps together, as a single piece. This permit to conserve the original muscle position in the absence of an underlying attachment to the bone and preserve cosmesis.

2. L.G. Kempe modified incision or midline sagittal incision with «T-bar»:

With this incision there is a better blood flow to the skin flaps, and so, lesser dehiscence risk, especially in the posterior portion of the incision, the weakness of the previously described incision [67]. The scalp is incised in the midline from the widow's peak to the inion, after this, is created a limb to the incision, forming the «T-bar» from $1-2 \mathrm{~cm}$ anterior to the tragus, extending superiorly, $1 \mathrm{~cm}$ behind the coronal suture until find the midline sagittal incision [65-67]

Skin incisions for bilateral decompressive craniectomies

Bilateral craniectomies are especially useful in cases of bilateral frontal contusions or generalized cerebral edema without focal lesion [65]. Can be performed in two ways:

1. Perform two hemicraniectomies as previously described:

This will result in the midline a strip of bone $2-3 \mathrm{~cm}$ wide, for covering the superior sagittal sinus. Can be used either the midline sagittal incision with «T-bar» or the large reverse question mark frontotemporoparietal incision [67].

\section{Kjellberg type}

In this, is made a standard bicoronal incision, beginning $1-2 \mathrm{~cm}$ anterior to the tragus, going superiorly behind the coronal suture until finding the opposite root of the zygoma, also ending $2 \mathrm{~cm}$ anterior to the tragus [66]. The flap resulting is reflected anteriorly and inferiorly exposing the frontal and anterior temporal lobes [67].

Making the bone flap for decompressive hemicraniectomy

Superior to the root of the zygoma is made a single bur hole, to delineate the floor of the temporal fossa. The asterion should be exposed by reflecting the soft tissue caudally. Making this maneuver can be visualized the inferior extent of the temporal and occipital lobes [67]. Already made the blur hole is inserted the footplate and the bone flap is turned by extending the beginning of the craniectomy along the line toward the inion. For avoiding the transverse sinus is necessary to stay at least $1-\mathrm{cm}$ rostral to the asterion. The lambdoid suture will be crossed when the bone flap is extended posteriorly, then, the drill bit is turned parallel to and $1-\mathrm{cm}$ medial to the lambdoid suture until reach a point $1 \mathrm{~cm}$ from the midline [67].

The drill is then turned parallel to the sagittal sinus, again crossing the lambdoid suture. Drilling continues toward the supraorbital bar. The craniotomy is continued anteriorly by hugging the floor of the frontal fossa as closely as possible, staying as close to the orbital rim as the anatomy allows. Next, the drill is turned posterolaterally toward the keyhole and aimed as close to the pterion as possible. At this point, the drill is removed and re-inserted into the bur hole at the root of the zygoma [67].

The second drill line is created by hugging the floor of the temporal fossa and extending it as far anteriorly as possible toward the temporal tip. The bone flap is removed by levering it using the pterion as fulcrum [67]. Usually the pterion cracks on removal and the dura can be dissected using Rhoton dissectors. Leksell rongeurs are used to remove bone excess, it is necessary to smooth the edges of the bone flap $[66,67]$.

Making bone flap for bilateral decompressive craniectomies

The bur holes are placed in the keyhole and in the root of the zygoma just below the superior temporal line. This type of craniectomy can be removed as a single piece or a strip of bone can be left over the sagittal sinus for protection, then resulting two bone flaps.

The bilateral frontal and subtemporal craniectomies will be performed, so the firs drill line extends from the zygoma, ascending and crossing the sagittal superior sinus until reach the contralateral zygoma, the a second drill line extends from keyhole to keyhole, crossing $1 \mathrm{~cm}$ parallel and superior to the orbital rim, then other tow drill lines will be performed, are made from the zygomatic bur hole going anteriorly, hugging the floor of the temporal fossa toward the temporal tip and extending superiorly and anteriorly toward the keyhole [67]. This will result in the exposing of the frontal and anterior temporal lobes. The craniectomy can be enlarged using Leksell rongeur, especialy the subtemporal craniectomy [66].

\section{Dural opening}

For this step can be used three different ways of opening the dura with fish-mouth incision, stellate incision, C-shaped fashion incision and cruciate incision $[66,68]$. The C-shaped fashion is one of the most used incisions for dural opening, it goes from the temporal tip of the temporal lobe, and curving back about $8 \mathrm{~cm}$ 
crossing the sylvian fissure, and ending in the frontal region [66]. For allow brain swelling can be practiced spoke-wheel relief cuts. The dural flap is reflected anteriorly. Now, the underlying hematomas can be evacuated. Once hemostasis is ensured, the dura leaves can be laid back over the brain surface [67], and a large piece of dural substitute is placed over the opened dura [66].

\section{Dural substitutes and sealants}

In dural closure can be used absorbable gelatin sponges like (Gelfoam, Pharmacia and Upjohn, Kalamazoo, MI), dural substitutes and dural sealants. The dura substitutes are designed to be either placed as an onlay over dural defects or sutured into place [69]. These could be autologous tissues, such as pericranium or fascia lata, or artificial dural substitutes mainly derived from bovine tendon (DuraGen, DuraGen Plus [Integra LifeSciences, Plainsboro, New Jersey, USA], DuraMatrix [Stryker, Cambridge, Massachusetts, USA], TissuDura [Baxter Healthcare S.A., Opfikon, Switzerland]), among others derived from fetal bovine skin [69].

With the aim to reinforce primarily repaired dura or as adjuncts to dural substitutes can be used the dural sealants, including DuraSeal (polyethylene glycol hydrogel [Confluent Surgical Inc., Waltham, Massachusetts, USA]), Bioglue (glutaraldehyde, bovine albumin [Cryolife, Kennesaw, Georgia, USA]), Tissucol (human fibrinogen, thrombin, albumin, and animal aprotinin), Tisseel (human fibrinogen, thrombin, and aprotinin [Baxter International Inc., Westlake Village, California, USA]), and Evicel (human fibrinogen and thrombin [Johnson and Johnson Wound Management, Ethicon Inc., Somerville, New Jersey, USA]) [69], Seprafilm (hyaluronate/carboxymethyl cellulose) [70].

\section{Skin closure}

The skin is closed over the absorbable gelatin sponge or the dura substitute or sealant using 2-0 Vicryl (Ethicon, Johnson \& Johnson Professionals, Inc., Somerville, NJ) stitches for the galea. Typically, staples are used to close the skin.

\section{Craniectomy bone flap management}

The craniectomy bone flap can be discarded, be inserted in an abdominal subcutaneous pocket in the left lower quadrant or conserved in a bone bank [66, $67,71]$. The consequences of discard the bone flap are obvious, requires a cranioplasty with intraoperative reconstruction, making expensive the procedure, and sacrificing cosmesis. In some centers are preferred discard it and use 3D methyl methacrylate prosthetic implants [66], especially because over one-half of the patients with severe CNS injury had concomitant systemic infectious processes of some type [66]. When the bone flap is conserved inside the body, it usually remolds the bone edges to some degree. So, keeping the bone frozen in a bone bank is an option with no risks of bone remodeling, and offers great cosmetic outcomes [67].

When the autogenous bone graft is not available for cranioplasty, can be used synthetic materials such as tantalum, silastic, titanium plate, prefabricated acrylic, synthetic bone substitute, and other similar material manufactured for the use of implantation into the body [71].

\section{WHAT IS AND WHAT IS NOT}

As has been stated clearly above, DC is a surgical procedure that reduces the secondary damage due to an uncontrolled increase of ICP, but does not heal the primary lesion [72]. Inappropriate techniques for DC, e.g., do not smooth the bony edges; do not try at maximum to do bone removal as large as possible performing wrong approaches like only subtemporal decompression, or only frontotemporal decompression, can generate iatrogenic brain lesion, and even generate brain herniation trough the craniectomy. Do not being faithful to the technique described can result in patient dead or in bad outcomes.

The inconsistent results and the conflicting opinions related to the $D C$ can be due to the substantial variation of its employment. It is imperative that DC must be performed with standardized technical guidelines as proposed by Quinn et al in 2010 [65].

\section{CONCLUSSIONS}

The cranial decompression techniques are saving surgeries in expert hands. Neurotrauma surgery is a complex surgery, usually performed by residents and young neurosurgeons. We suggest the use of a checklist during decompressive craniectomy that ensures that the procedure is performed correctly.

\section{References}

1. Cooper PR, Rovit RL, Ransohoff J. Hemicraniectomy in the treatment of acute subdural hematoma: a re-appraisal. Surg Neurol. 1976 Jan;5(1):25-8. PubMed PMID: 1265621. Epub 1976/01/01. eng.

2. Ransohoff J, Benjamin V. Hemicraniectomy in the treatment of acute subdural haematoma. Journal of neurology, neurosurgery, and psychiatry. 1971 Feb;34(1):106. PubMed PMID: 5551680. Pubmed Central PMCID: PMC493703. Epub 1971/02/01. eng.

3. Kocher T. Die Therapie des Hirndruckes. In: Verlag $H$, editor. Hirnerschutterung, Hirndruck und chirurgische Eingriffe bei Hirnkrankheiten1901. p. 262-6.

4. Honeybul S. Decompressive Craniectomy for Severe Traumatic Brain Injury: A Review of its Current Status. Neurol Neurophysiol. 2012:S9.

5. Cushing $\mathrm{H}$. Establishment of cerebral hernia as a decompressive measure for inaccessible brain tumors 1905.

6. Cushing H. I. Subtemporal Decompressive Operations for the Intracranial Complications Associated with Bursting Fractures of the Skull. Annals of surgery. 1908 May;47(5):641-4 1. PubMed PMID: 17862145 . Pubmed Central PMCID: PMC1414584. Epub 1908/05/01. eng.

7. Cooper PR, Hagler H, Clark WK, Barnett P. Enhancement of experimental cerebral edema after decompressive craniectomy: implications for the management of severe head injuries. Neurosurgery. 1979 Apr;4(4):296-300. PubMed PMID: 450227. Epub 1979/04/01. eng.

8. Clark K, Nash TM, Hutchison GC. The failure of circumferential craniotomy in acute traumatic cerebral swelling. Journal of neurosurgery. 1968 Oct;29(4):367-71. PubMed PMID: 5303377. Epub 1968/10/01. eng.

9. Kjellberg RN, Prieto A, Jr. Bifrontal decompressive craniotomy for massive cerebral edema. Journal of neurosurgery. 1971 Apr;34(4):488-93. PubMed PMID: 5554353. Epub 1971/04/01. eng.

10. Venes JL, Collins WF. Bifrontal decompressive craniectomy in the management of head trauma. Journal of neurosurgery. 1975 Apr;42(4):429-33. PubMed PMID: 1123660. Epub 1975/04/01. eng.

11. Pereira WC, Neves VJ, Rodrigues Y. [Bifrontal decompressive craniotomy as the treatment for severe cerebral edema]. Arquivos de neuro-psiquiatria. 1977 Jun;35(2):99-111. PubMed PMID: 869742. Epub 1977/06/01. Craniotomia 
descompressive bifrontal no tratamento do edema cerebral grave. por.

12. Gerl A, Tavan S. [Bilateral craniectomy in the treatment of severe traumatic brain edema]. Zentralblatt fur Neurochirurgie. 1980;41(2):125-38. PubMed PMID: 7435005. Epub 1980/01/01. Die bilaterale Kraniektomie zur Behandlung des schweren traumatischen Hirnodems. ger.

13. Gaab MR, Rittierodt M, Lorenz M, Heissler HE. Traumatic brain swelling and operative decompression: a prospective investigation. Acta neurochirurgica Supplementum. 1990;51:326-8. PubMed PMID: 2089928. Epub 1990/01/01. eng.

14. Plesnila N. Decompression craniectomy after traumatic brain injury: recent experimental results. Progress in brain research. 2007;161:393-400. PubMed PMID: 17618993. Epub 2007/07/10. eng.

15. Zweckberger K, Eros C, Zimmermann R, Kim SW, Engel D, Plesnila N. Effect of early and delayed decompressive craniectomy on secondary brain damage after controlled cortical impact in mice. Journal of neurotrauma. $2006 \mathrm{Jul} ; 23(7): 1083-$ 93. PubMed PMID: 16866621. Epub 2006/07/27. eng.

16. Mezue WC, Erechukwu AU, Ndubuisi C, Ohaegbulam SC, Chikani MC. Severe traumatic brain injury managed with decompressive craniectomy. Nigerian journal of clinical practice. 2012 Jul-Sep;15(3):369-71. PubMed PMID: 22960979. Epub 2012/09/11. eng.

17. Akyuz M, Ucar T, Acikbas C, Kazan S, Yilmaz M, Tuncer R. Effect of early bilateral decompressive craniectomy on outcome for severe traumatic brain injury. Turkish neurosurgery. 2010 Jul;20(3):382-9. PubMed PMID: 20669113. Epub 2010/07/30. eng.

18. Hyder AA, Aggarwal A. The increasing burden of injuries in Eastern Europe and Eurasia: Making the case for safety investments. Health Policy. 2009 1//;89(1):1-13.

19. Murray CJ, Lopez AD. Alternative projections of mortality and disability by cause 1990-2020: Global Burden of Disease Study. Lancet. 1997 May 24;349(9064):1498-504. PubMed PMID: 9167458. Epub 1997/05/24. eng.

20. Prevention CfDC. Traumatic brain injury in the United States: A report to Congress. 1999.

21. Coronado VG, McGuire LC, Sarmiento K, Bell J, Lionbarger $M R$, Jones $C D$, et al. Trends in Traumatic Brain Injury in the U.S. and the public health response: 1995-2009. Journal of Safety Research. 2012 9//;43(4):299-307.

22. Zygun DA, Kortbeek JB, Fick GH, Laupland KB, Doig CJ. Nonneurologic organ dysfunction in severe traumatic brain injury. Critical care medicine. 2005 Mar;33(3):654-60. PubMed PMID: 15753760. Epub 2005/03/09. eng.

23. Wade AL, Dye JL, Mohrle CR, Galarneau MR. Head, face, and neck injuries during Operation Iraqi Freedom II: results from the US Navy-Marine Corps Combat Trauma Registry. The Journal of trauma. 2007 Oct;63(4):836-40. PubMed PMID: 18090014. Epub 2007/12/20. eng.

24. Berthiaume L, Zygun D. Non-neurologic organ dysfunction in acute brain injury. Critical care clinics. 2006 Oct;22(4):75366; abstract x. PubMed PMID: 17239753. Epub 2007/01/24. eng.

25. Pilitsis JG, Rengachary SS. Complications of head injury. Neurological research. 2001 Mar-Apr;23(2-3):227-36. PubMed PMID: 11320604. Epub 2001/04/26. eng.

26. Goodman MD, Makley AT, Lentsch AB, Barnes SL, Dorlac GR, Dorlac WC, et al. Traumatic Brain Injury and Aeromedical Evacuation: When is the Brain Fit to Fly? Journal of Surgical Research. 2010 12//;164(2):286-93.

27. Graves JM, Sears JM, Vavilala MS, Rivara FP. The burden of traumatic brain injury among adolescent and young adult workers in Washington State. Journal of Safety Research. $2012(0)$.

28. Galarneau MR, Woodruff SI, Dye JL, Mohrle CR, Wade $A L$. Traumatic brain injury during Operation Iraqi Freedom: findings from the United States Navy-Marine Corps Combat Trauma Registry. Journal of neurosurgery. 2008 May;108(5):950-7. PubMed PMID: 18447712. Epub 2008/05/02. eng.

29. Okie S. Traumatic brain injury in the war zone. The New England journal of medicine. 2005 May 19;352(20):2043-7. PubMed PMID: 15901856. Epub 2005/05/20. eng.

30. Pujol J, Vendrell P, Junque C, Marti-Vilalta JL, Capdevila
A. When does human brain development end? Evidence of corpus callosum growth up to adulthood. Annals of neurology. 1993 Jul;34(1):71-5. PubMed PMID: 8517683. Epub 1993/07/01. eng.

31. Faul M, Xu L, Wald M, Coronado V. Traumatic brain injury in the United States: Emergency department visits, hospitalizations and deaths 2002-2006; Atlanta, GA: Centers for Disease Control and Prevention 2010. Available from: http://www.cdc. gov/traumaticbraininjury/pdf/blue_book.pdf.

32. Anderson V, Brown S, Newitt H, Hoile H. Long-term outcome from childhood traumatic brain injury: intellectual ability, personality, and quality of life. Neuropsychology. 2011 Mar;25(2):176-84. PubMed PMID: 21219074. Epub 2011/01/12. eng.

33. Doctor JN, Castro J, Temkin NR, Fraser RT, Machamer JE, Dikmen SS. Workers' risk of unemployment after traumatic brain injury: a normed comparison. Journal of the International Neuropsychological Society : JINS. 2005 Oct;11(6):74752. PubMed PMID: 16248910. Epub 2005/10/27. eng.

34. Todis B, Glang A, Bullis M, Ettel D, Hood D. Longitudinal investigation of the post-high school transition experiences of adolescents with traumatic brain injury. The Journal of head trauma rehabilitation. 2011 Mar-Apr;26(2):138-49. PubMed PMID: 20631630. Epub 2010/07/16. eng.

35. Whitmore RG, Thawani JP, Grady MS, Levine JM, Sanborn MR, Stein SC. Is aggressive treatment of traumatic brain injury cost-effective? Journal of neurosurgery. 2012 May;116(5):1106-13. PubMed PMID: 22394292. Epub 2012/03/08. eng.

36. Maghool F, Khaksari M, khachki As. Differences in brain edema and intracranial pressure following traumatic brain injury across the estrous cycle: involvement of female sex steroid hormones. Brain Research. 2012 (0).

37. Patro A, Mohanty S. Pathophysiology and treatment of traumatic brain edema. The Indian Journal of Neurotrauma. $20096 / / ; 6(1): 11-5$.

38. Barker-Collo SL, Starkey N, Kahan M, Theadom A, Feigin $V$. Computerised tomography indices of raised intracranial pressure and traumatic brain injury severity in a New Zealand sample. The New Zealand medical journal. 2012 Aug 24;125(1360):92-4. PubMed PMID: 22932663. Epub 2012/08/31. eng.

39. Egea-Guerrero JJ, Gordillo-Escobar E, Revuelto-Rey J, Enamorado-Enamorado J, Vilches-Arenas A, PachecoSanchez $M$, et al. Clinical variables and neuromonitoring information (intracranial pressure and brain tissue oxygenation) as predictors of brain-death development after severe traumatic brain injury. Transplantation proceedings. 2012 Sep;44(7):2050-2. PubMed PMID: 22974906. Epub 2012/09/15. eng.

40. Frutos Bernal E, Rubio Gil FJ, Martin Corral JC, Marcos Prieto LA, Gonzalez Robledo J. Prognostic factors in severe traumatic brain injury. Medicina intensiva / Sociedad Espanola de Medicina Intensiva y Unidades Coronarias. 2012 Jul 30. PubMed PMID: 22854619. Epub 2012/08/03. Factores pronosticos del traumatismo craneoencefalico grave. Eng Spa.

41. Abdalla Mohamed A, Ahmed Ibrahim W, Fayez Safan T. Hemodynamic and intracranial pressure changes in children with severe traumatic brain injury. Egyptian Journal of Anaesthesia. 2011 10//;27(4):273-8.

42. Geeraerts T, Menon DK. Le monitorage de la pression intracranienne ameliore-t-il le devenir des traumatises craniens graves ? Annales Francaises d'Anesthesie et de Reanimation. 2010 9//;29(9):e171-e5.

43. Armonda RA, Tigno TA, Hochheimer SM, Stephens FL, Bell $\mathrm{RS}$, Vo AH, et al. Posttraumatic vasospasm and intracranial hypertension after wartime traumatic brain injury. Perspectives in Medicine. 2012 9//;1(1-12):261-4.

44. Zeng T, Gao L. Management of patients with severe traumatic brain injury guided by intraventricular intracranial pressure monitoring: a report of 136 cases. Chinese Journal of Traumatology (English Edition). 2010 6//;13(3):146-51.

45. Little RD. Increased Intracranial Pressure. Clinical Pediatric Emergency Medicine. 2008 6//;9(2):83-7.

46. Clifton GL, Miller ER, Choi SC, Levin HS. Fluid thresholds and outcome from severe brain injury. Critical care medicine. 2002 Apr;30(4):739-45. PubMed PMID: 11940738. Epub 2002/04/10. eng. 
47. Juul N, Morris GF, Marshall SB, Marshall LF. Intracrania hypertension and cerebral perfusion pressure: influence on neurological deterioration and outcome in severe head injury. The Executive Committee of the International Selfotel Trial. Journal of neurosurgery. 2000 Jan;92(1):1-6. PubMed PMID: 10616075. Epub 2000/01/01. eng.

48. Marmarou $A$. Increased intracranial pressure in head injury and influence of blood volume. Journal of neurotrauma. 1992 Mar;9 Suppl 1:S327-32. PubMed PMID: 1588624. Epub 1992/03/01. eng.

49. Ciurea AV, Coman T, Rosu L, Ciurea J, Baiasu S. Severe brain injuries in children. Acta neurochirurgica Supplement. 2005;93:209-12. PubMed PMID: 15986758. Epub 2005/07/01. eng.

50. Ropper A, Samuels M. Adams and Victor's Principles of Neurology. Ninth ed2009.

51. Rodriguez-Boto G, Rivero-Garvia M, Gutierrez-Gonzalez R, Marquez-Rivas J. Basic concepts about brain pathophysiology and intracranial pressure monitoring. Neurologia (Barcelona, Spain). 2012 Dec 12. PubMed PMID: 23246212. Epub 2012/12/19. Conceptos basicos sobre la fisiopatologia cerebral y la monitorizacion de la presion intracraneal. Eng Spa.

52. Raslan A, Bhardwaj A. Medical management of cerebral edema. Neurosurgical focus. 2007;22(5):E12. PubMed PMID: 17613230. Epub 2007/07/07. eng.

53. Cooper DJ, Rosenfeld JV, Murray L, Wolfe R, Ponsford J, Davies A, et al. Early decompressive craniectomy for patients with severe traumatic brain injury and refractory intracranial hypertension-A pilot randomized trial. Journal of Critica Care. 2008 9//;23(3):387-93.

54. Sadaka F, Veremakis C. Therapeutic hypothermia for the management of intracranial hypertension in severe traumatic brain injury: a systematic review. Brain injury : [BI] 2012;26(7-8):899-908. PubMed PMID: 22448655. Epub 2012/03/28. eng.

55. Kan EM, Ling E-A, Lu J. Microenvironment changes in mild traumatic brain injury. Brain Research Bulletin. 2012 3/10/;87(4-5):359-72.

56. Marmarou A, Signoretti S, Aygok G, Fatouros P, Portella G. Traumatic brain edema in diffuse and focal injury: cellular or vasogenic? Acta neurochirurgica Supplement. 2006;96:24-9. PubMed PMID: 16671417. Epub 2006/05/05. eng.

57. Marmarou A. Pathophysiology of traumatic brain edema: current concepts. Acta neurochirurgica Supplement. 2003;86:710. PubMed PMID: 14753394. Epub 2004/02/03. eng.

58. Cremer OL, van Dijk GW, van Wensen E, Brekelmans GJ, Moons KG, Leenen LP, et al. Effect of intracranial pressure monitoring and targeted intensive care on functional outcome after severe head injury. Critical care medicine. 2005 Oct;33(10):2207-13. PubMed PMID: 16215372. Epub 2005/10/11. eng.

59. Balestreri $M$, Czosnyka $M$, Hutchinson $P$, Steiner LA, Hiler $M$, Smielewski $P$, et al. Impact of intracranial pressure and cerebral perfusion pressure on severe disability and mortality after head injury. Neurocritical care. 2006;4(1):8-13. PubMed
PMID: 16498188. Epub 2006/02/25. eng.

60. Stocchetti N, Colombo A, Ortolano F, Videtta W, Marchesi $R$, Longhi $L$, et al. Time course of intracranial hypertension after traumatic brain injury. Journal of neurotrauma. 2007 Aug;24(8):1339-46. PubMed PMID: 17711395. Epub 2007/08/23. eng.

61. Oddo M, Levine JM, Mackenzie L, Frangos S, Feihl F, Kasner $\mathrm{SE}$, et al. Brain hypoxia is associated with short-term outcome after severe traumatic brain injury independently of intracranial hypertension and low cerebral perfusion pressure. Neurosurgery. 2011 Nov;69(5):1037-45; discussion 45 PubMed PMID: 21673608. Epub 2011/06/16. eng.

62. Holland M, Nakaji P. Craniectomy: surgical indications and technique. Operative Techniques in Neurosurgery. 2004 $3 / / ; 7(1): 10-5$

63. Li LM, Timofeev I, Czosnyka M, Hutchinson PJ. Review article: the surgical approach to the management of increased intracranial pressure after traumatic brain injury. Anesthesia and analgesia. 2010 Sep;111(3):736-48. PubMed PMID: 20686006. Epub 2010/08/06. eng.

64. Bell RS, Mossop CM, Dirks MS, Stephens FL, Mulligan L, Ecker R, et al. Early decompressive craniectomy for severe penetrating and closed head injury during wartime. Neurosurgical focus. 2010 May;28(5):E1. PubMed PMID: 20568925. Epub 2010/06/24. eng.

65. Quinn TM, Taylor JJ, Magarik JA, Vought E, Kindy MS, Ellegala DB. Decompressive craniectomy: technical note. Acta neurologica Scandinavica. 2011 Apr;123(4):239-44. PubMed PMID: 20637010. Epub 2010/07/20. eng.

66. Ragel BT, Klimo P, Jr., Martin JE, Teff RJ, Bakken HE, Armonda RA. Wartime decompressive craniectomy: technique and lessons learned. Neurosurgical focus. 2010 May;28(5):E2 PubMed PMID: 20568936. Epub 2010/06/24. eng.

67. Mitchell $P$, Gregson BA, Vindlacheruvu RR, Mendelow AD. Surgical options in ICH including decompressive craniectomy. Journal of the Neurological Sciences. 2007 10/15/;261(12):89-98.

68. Johnson RD, Maartens NF, Teddy PJ. Technical aspects of decompressive craniectomy for malignant middle cerebral artery infarction. Journal of Clinical Neuroscience. 2011 8//;18(8):1023-7.

69. Sekhar LN, Mai JC. Dural Repair After Craniotomy and the Use of Dural Substitutes and Dural Sealants. World Neurosurgery. (0).

70. Mumert ML, Altay T, Couldwell WT. Technique for decompressive craniectomy using Seprafilm as a dural substitute and anti-adhesion barrier. Journal of Clinical Neuroscience. 2012 3//;19(3):455-7.

71. Senapati SB, Sekhar Mishra S, Das S, Chandra Satpathy P. Cranioplasty after decompressive craniectomy. The Indian Journal of Neurotrauma. (0).

72. Pereyra C, Benito Mori L, Schoon P, Violi D, Jacintho P, Segui G, et al. Decompressive Craniectomy and Brain Death Prevalence and Mortality: 8-Year Retrospective Review. Transplantation proceedings. 2012 9//;44(7):2181-4. 
Luis Rafael Moscote-Salazar ${ }^{1}$, Hernando Raphael Alvis-Miranda ${ }^{1}$, Gabriel Alcala-Cerra ${ }^{1}$, Andres M. Rubian 2, 3

1 Department of Neurosurgery, University of Cartagena, Cartagena, Colombia

2 Faculty of Medicine, South Colombian University, Neiva, Colombia

3 Director, The Foundation for Medical Education and Research «Meditech», Neiva, Colombia

\title{
Декомпресивна краніоектомія при черепно-мозковій травмі: Камо грядеши?
}

Внутрішньочерепна гіпертензія $\epsilon$ провідною причиною смертності у потерпілих при черепно-мозковій травмі. У теперішній час травма голови $\epsilon$ проблемою охорони здоров'я в усьому світі. Декомпресивна краніоектомія - провідна стратегія лікування пацієнтів з приводу рефрактерної внутрішньочерепної гіпертензії. Виконання краніоектомії вимагає досконалої і ретельної хірургічної техніки. Представляємо огляд літератури з питань техніки виконання краніоектомії.

Ключові слова: нейротравма, травма голови, декомпресивна краніоектомія.

Укр. нейрохірург. журн. - 2014. - №4. - С.4-10.

Надійшла до редакції 14.08.14. Прийнята до публікації 19.09.2014.

Адреса для листування: Dr. Luis Rafael Moscote-Salazar, University of Cartagena, Cartagena, Colombia, e-mail: mineurocirujano@gmail.com

\author{
Luis Rafael Moscote-Salazar ${ }^{1}$, Hernando Raphael Alvis-Miranda 1, Gabriel Alcala-Cerra ${ }^{1}$, \\ Andres M. Rubian ${ }^{2,3}$ \\ 1 Department of Neurosurgery, University of Cartagena, Cartagena, Colombia \\ 2 Faculty of Medicine, South Colombian University, Neiva, Colombia \\ 3 Director, The Foundation for Medical Education and Research «Meditech», Neiva, Colombia
}

\section{Декомпрессивная краниоэктомия при черепно-мозговой травме: Камо грядеши?}

Внутричерепная гипертензия является ведущей причиной смертности пострадавших при черепномозговой травме. В настоящее время травма головы является проблемой здравоохранения во всем мире. Декомпрессивная краниоэктомия - ведущая стратегия лечения пациентов по поводу рефрактерной внутричерепной гипертензии. Выполнение краниоэктомии требует совершенной и тщательной хирургической техники. Представляем обзор литературы, посвященный технике выполнения краниоэктомии.

Ключевые слова: нейротравма, травма головы, декомпрессивная краниоэктомия.

Укр. нейрохірург. журн. - 2014. - №4. - С.4-10.

Поступила в редакцию 14.08.14. Принята к публикации 19.09.14.

Адрес для переписки: Dr. Luis Rafael Moscote-Salazar, University of Cartagena, Cartagena, Colombia, e-mail: mineurocirujano@gmail.com 